\title{
Library Protocol
}

National Cancer Institute

\section{Source}

National Cancer Institute. Library Protocol. NCI Thesaurus. Code C41111.

Laboratory protocol used to prepare a Library. 